DISTRIBUTION STATEMENT A. Approved for public release; distribution is unlimited.

\title{
Development of a Long-Range Underwater Vehicle
}

\author{
Russ E. Davis \\ Scripps Institution of Oceanography, University of California San Diego \\ 9500 Gilman Drive \\ La Jolla, CA 92093-0230 \\ phone: (858) 5344415 email: rdavis@ucsd.edu \\ Jeffrey T. Sherman \\ Scripps Institution of Oceanography, University of California San Diego \\ 9500 Gilman Drive \\ La Jolla, CA 92093-0213 \\ phone: (858) 5349863 email: jtsherman@uscd.edu
}

Award Number: N00014-13-1-0455

\section{LONG-TERM GOALS}

Our overall goal is to increase the capabilities of today's Unmanned Underwater Vehicles (UUVs) and Unmanned Underwater Gliders (UUGs) by using high energy-density lithium-seawater batteries. Specific objectives are (1) to test in the laboratory and ocean new lithium-seawater batteries developed and manufactured by the PolyPlus Battery Company, (2) to discover how to mount and operate these cells to maximize their mass transfer with the ambient seawater and to minimize the adverse impacts of bio-fouling, and (3) to develop a long-range underwater UUV or UUG to exploit this energy source. Our target is to double the range/duration of long-range neutrally buoyant underwater vehicles.

\section{OBJECTIVES}

Based on reaction energy and reactant mass, oxidation of lithium is particularly attractive for high energy-density batteries. Each gram of lithium can supply 3.8 A hr of current at a voltage, depending on the reaction leading to lithium oxidation, of 2.6 to $3.5 \mathrm{~V}$. The no-load potentials, E, of the primary lithium-oxygen and lithium-water couples likely in seawater are

Oxygen reduction in seawater

Hydrogen evolution in seawater

$$
\begin{array}{ll}
4 \mathrm{Li}+\mathrm{O}_{2}+2 \mathrm{H}_{2} \mathrm{O}=4 \mathrm{LiOH} & \mathrm{E} \sim 3.45 \mathrm{~V} \\
2 \mathrm{Li}+2 \mathrm{H}_{2} \mathrm{O}=2 \mathrm{LiOH}+\mathrm{H}_{2} & \mathrm{E} \sim 2.60 \mathrm{~V}
\end{array}
$$

The theoretical energies per unit mass of reactant of these reactions are $13.3 \mathrm{~kW} \mathrm{hr} \mathrm{kg}{ }^{-1}\left(49 \mathrm{MJ} \mathrm{kg}^{-1}\right)$ and $9.9 \mathrm{~kW} \mathrm{hr} \mathrm{kg}^{-1}$ (36 $\mathrm{MJ} \mathrm{kg}^{-1}$ ), respectively. The achievable energy density for batteries is much less.

PolyPlus Battery Company has developed a lithium-seawater battery (http://polyplus.com/liwater.html) suitable for underwater vehicles that has very high energy density. Each cell has a Protected Lithium Electrode in which a "solid electrolyte" membrane, that passes lithium ions but not water molecules, 


\section{Report Documentation Page}

Form Approved

OMB No. 0704-0188

Public reporting burden for the collection of information is estimated to average 1 hour per response, including the time for reviewing instructions, searching existing data sources, gathering and maintaining the data needed, and completing and reviewing the collection of information. Send comments regarding this burden estimate or any other aspect of this collection of information,

including suggestions for reducing this burden, to Washington Headquarters Services, Directorate for Information Operations and Reports, 1215 Jefferson Davis Highway, Suite 1204, Arlington

VA 22202-4302. Respondents should be aware that notwithstanding any other provision of law, no person shall be subject to a penalty for failing to comply with a collection of information if it

does not display a currently valid OMB control number.

1. REPORT DATE

30 SEP 2014

4. TITLE AND SUBTITLE

Development of a Long-Range Underwater Vehicle

6. AUTHOR(S)

7. PERFORMING ORGANIZATION NAME(S) AND ADDRESS(ES)

University of California San Diego,Scripps Institution of Oceanography,9500 Gilman Drive,La Jolla,CA,92093

9. SPONSORING/MONITORING AGENCY NAME(S) AND ADDRESS(ES)

\section{DATES COVERED}

00-00-2014 to 00-00-2014

5a. CONTRACT NUMBER

5b. GRANT NUMBER

5c. PROGRAM ELEMENT NUMBER

5d. PROJECT NUMBER

5e. TASK NUMBER

5f. WORK UNIT NUMBER

8. PERFORMING ORGANIZATION

REPORT NUMBER

10. SPONSOR/MONITOR'S ACRONYM(S)

11. SPONSOR/MONITOR'S REPORT

NUMBER(S)

12. DISTRIBUTION/AVAILABILITY STATEMENT

Approved for public release; distribution unlimited

13. SUPPLEMENTARY NOTES

14. ABSTRACT

15. SUBJECT TERMS

16. SECURITY CLASSIFICATION OF:

a. REPORT

unclassified b. ABSTRACT

unclassified c. THIS PAGE

unclassified
17. LIMITATION OF ABSTRACT

Same as

Report (SAR)
18. NUMBER 19a. NAME OF

OF PAGES RESPONSIBLE PERSON

6 
separates the lithium anode from seawater. The cell combines this anode with cathodes optimized for oxygen reduction and operates in seawater at ocean depths. PolyPlus has tested these cells under laboratory conditions with excellent performance and has achieved energy densities near $4.7 \mathrm{MJ} / \mathrm{kg}$, four times that available from the primary lithium batteries used in floats and gliders today. The seawater cells are also substantially safer.

The objectives of our project, which correspond to the phases of work, are:

1. Test PolyPlus lithium-seawater cells to define their capabilities for use in marine vehicles

2. Design a prototype long-range underwater vehicle to exploit the new power source

3. Build and report the field performance of the prototype vehicle with lithium-seawater batteries.

\section{APPROACH}

Russ Davis and Jeff Sherman of Scripps are collaborating with Steve Visco and Eugene Nimon of PolyPlus on this work. Visco, founder and CEO of PolyPlus, and Nimon, Director of Research and Development, are essential technical resources for planning and interpreting tests of the lithiumseawater batteries. PolyPlus provides the batteries for testing. Sherman and Davis, who developed the Spray glider and other ocean technologies, will design and build test facilities, carry out field tests, and head up design and construction of the prototype vehicle.

The approach for the testing phase was to characterize performance of the batteries in laboratory tests and then carry them to sea for multi-month missions as "passive passengers" on Spray gliders. Laboratory tests provide a well controlled environment for pressure cycling and measuring cell performance under different electrical and hydrodynamic conditions. Field missions expose the cells to realistic conditions and including biological fouling.

Major design goals are to (a) compare battery suitability for propeller-driven UUVs and UUGs that use buoyancy change for propulsion, (b) ) achieve the good mass transfer needed for cell performance without adding excessive vehicle drag, (c) provide useful power from seawater batteries that are best operated continuously near their average power and cannot be connected in series to increase operating voltage, and (d) take advantage of vehicle size and weight savings in the pressure case made possible by batteries that operate in ambient seawater. These are approached through engineering design, computer simulation and laboratory tests to measure mass transfer and drag. Field tests will, of course, determine both the real-world performance of the vehicle with seawater batteries and the operational requirements for using them.

\section{WORK COMPLETED}

The specific issues in the battery testing phase were (a) confirming that the anodes are not harmed by pressure cycling, (b) documenting how mass transfer between the cell electrodes and seawater affects cell voltage vs. current and what is required keep voltage from being greatly reduced by depleted reactants or precipitate formation on the cathode, and (c) understanding how biofouling around the cells affects mass transfer and how to minimize it.

A laboratory pressure tank was used for extensive pressure cycling tests of the seawater batteries. Microscopic examination of the electrodes and electrical-performance tests were used to detect any 
damage. This was necessary to verify that the fragile solid electrolyte material that protects the lithium in the anode is not fractured as depletion of the lithium creates a potential for stress concentrations.

A rotating arm was used to test the performance of individual batteries at different through-water speeds in a quiescent atmospheric-pressure tank of seawater. Changing electrical loads exercised the cells at different electrode current densities while cell voltage and its time behavior were measured.

Cell performance under ocean conditions was measured by mounting a pair of cells as a passive test package in the stern of a Spray glider. This enabled inexpensive multi-month exposure of the cells under realistic operational conditions. During a cruise, test batteries were connected to different electrical loads as their host Spray glider cycled vertically recording cell voltage, water temperature, salinity and oxygen concentration. Biofouling was characterized in post-cruise examination.

Two Spray missions with PolyPlus cells were carried out off the California coast. The first exposed aspects of cell behavior not accounted for in the test design. A second test of two cells lasted 69 days covering 729 dives, most to $400 \mathrm{~m}$. Ocean temperature, salinity and oxygen profiles were measured with an SBE41CP CTD and an SBE43F oxygen sensor. This test provided high-quality performance data under a range of operating and environmental conditions including significant biofouling.

We have begun the design phase by addressing two key issues: (a) What class of vehicles can best take advantage of the seawater batteries? and (b) How can the mass transfer required to bring reactants to, and remove products from, the cell electrodes be achieved with minimum drag penalty?

\section{RESULTS}

Extensive pressure cycling in the laboratory and field to 400 decibars showed no performance degradation or visible damage to the Protected Lithium Electrode. This electrode, when mounted in a cell, is robust in normal handling and field use. The cell cathodes, thin layers of a porous mat, are easily distorted in handling or field use; the eventual mounting scheme must account for this.

As reference for mass transfer in field studies, battery output was measured from cells moving at speeds of 5 to $12 \mathrm{~cm} / \mathrm{s}$ through quiescent seawater saturated with oxygen. At electrode current densities less than $0.3 \mathrm{ma} / \mathrm{cm}^{2}$, cell voltage varied only $\mathrm{O}(1 \%)$ over this speed range. Evidently, with welloxygenated water, normal glider speeds and current densities $<0.3 \mathrm{ma} / \mathrm{cm}^{2}$, direct mas-transfer limitations should be minimal. The cathode reaction produces hydroxide ions and can precipitate seawater salts like $\mathrm{CaCO}_{3}$ into the cathode mat, reducing cell output. In laboratory tests, no precipitates were observed below $0.3 \mathrm{ma} / \mathrm{cm}^{2}$, but the tests were only hours long. Unexpectedly, cells exhibited an $\mathrm{O}(30 \mathrm{sec})$ time constant responding to load changes. This is an order of magnitude greater than the cell's L/U time, and presumably reflects slow flushing of the porous cathode mat.

For field trials two seawater cells were mounted below Spray's tail section. At the field site, $\mathrm{O}_{2}$ was saturated near the surface, $50 \%$ saturated at $50 \mathrm{~m}$, and $10 \%$ at $400 \mathrm{~m}$. Performance below $50 \mathrm{~m}$, where $\mathrm{O}_{2}$ was depleted, differed from laboratory behavior in two respects: cell output was reduced more than the thermodynamic effect of the ambient $\mathrm{O}_{2}$ concentration on open-circuit cell voltage; and cell response to changing loads slowed, sometimes reaching $\mathrm{O}(5)$ minutes. Both effects were strongest with heavy loads, low $\left[\mathrm{O}_{2}\right]$, and ascending flow when flushing of the cells below the hull was reduced. Mass-transfer effects not significant in lab tests became significant as $\mathrm{O}_{2}$ concentration declined. 
Field performance is summarized in Figure 1 where equilibrium voltage is plotted against the log of dissolved $\left[\mathrm{O}_{2}\right]$; colors indicate loads of $1,3,6$ and $40 \mathrm{k} \Omega$. Three performance regimes are apparent: at high $\left[\mathrm{O}_{2}\right]$, voltage declines gradually with $\left[\mathrm{O}_{2}\right]$ but significantly with load; as $\left[\mathrm{O}_{2}\right]$ decreases further there is a transition to a steeper $\mathrm{V}$ vs $\mathrm{O}_{2}$; at high current density and low $\left[\mathrm{O}_{2}\right]$ the $\mathrm{V}$ vs. $\mathrm{O}_{2}$ slope is very steep. A cluster of low-oxygen points under the $1 \mathrm{k} \Omega$ load shows a steady cell voltage of $2.3 \mathrm{~V}$ indicating that the cathode reaction had switched from oxygen consumption to hydrogen evolution.

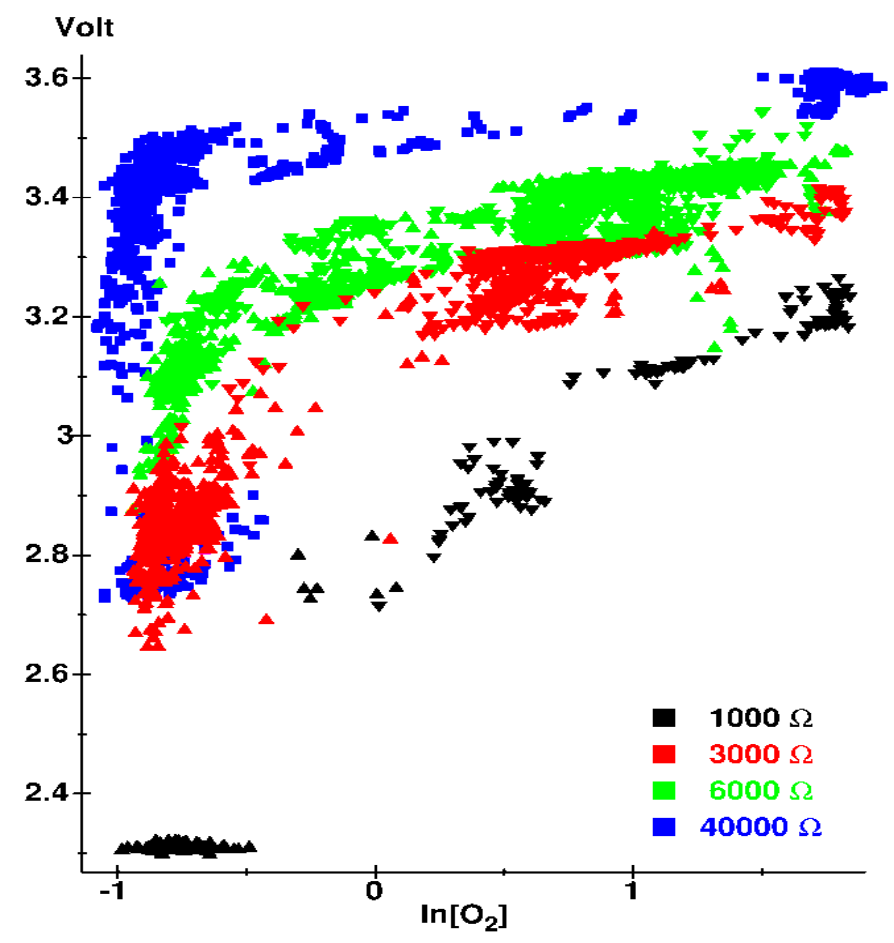

Figure 1. Cell voltage vs $\ln \left[\mathrm{O}_{2]}(\right.$ in $\mathrm{ml} / \mathrm{l})$ under various electrical loads in a field trial.

Post cruise inspection showed substantial biofouling around the electrodes and somewhat less on them. Immature barnacles, some whose “foot” approached cell dimensions, were common. Inorganic deposits were found in the porous cathode mat and between the electrodes, occasionally connecting the amode and a cathode. Friability and makeup showed these to be precipitates caused by high-pH at the cathode. Even at current densities of $0.3 \mathrm{ma} \mathrm{cm}^{-2}$, cell flushing was inadequate to avoid precipitation. Although fouling and precipitates were clearly evident, they did not degrade cell performance measurably.

With lab results in hand, design studies addressed what class of vehicle would best demonstrate the utility of the lithium-seawater battery. With electrode current densities below $0.3 \mathrm{ma} \mathrm{cm}^{-2}$, the battery's power density is low, but at this current density practical lithium thicknesses can support continuous discharge for $\mathrm{O}(100)$ days. The only present vehicles with this duration are gliders. While the more continuous energy demand of propeller propulsion is better suited to the seawater batteries, existing UUVs do not have the duration to fully exploit the PolyPlus batteries. Rather than design a new long-duration UUV to exercise the batteries, we have chosen to adapt glider technology to the job and focus on the issues associated with using lithium-seawater batteries themselves. 
Oxygen concentration generally declines rapidly with depth while cell voltage and energy are reduced by up to one-third as $\mathrm{O}_{2}$ is depleted. PolyPlus reports that cathodes optimized for oxygen reduction perform poorly in that role after having produced hydrogen. The data in Fig. 1 show cells evolving hydrogen and no performance decline was observed. It would be very helpful if an electrode could be used alternately for both reactions. The efficiency of deep operations depends on this. Shallow operation with oxygen consumption maximizes energy availability; deep operation evolving hydrogen makes glider flight more efficient; if both cell reactions could be used alternately, operating flexibility would increase markedly. We will begin the critical test of how well the cathodes perform when alternating between reactions as soon as more cells are received from PolyPlus.

The final conceptual-design question is how to achieve good cell flushing without adding too much vehicle drag. Flushing provides oxygen to the cathode and eliminates high $\mathrm{pH}$ cathode products that precipitate salts like $\mathrm{CaCO}_{3}$. To size the issue, it takes 100 to 125 cells that are $5 \mathrm{~cm}$ by $5 \mathrm{~cm}$ to provide double the available energy for today's gliders. The cells are sandwiches, roughly $1 \mathrm{~cm}$ thick, with the anode suspended between a pair of the cloth-like cathodes (the bread). Flushing occurs through the four 5-cm-long edges and through the permeable cathode material.

Strategies for mounting are to array cells edge-to-edge into flat surfaces parallel to the flow or line them up side-by-side with edge-on flow. For edge-to-edge mounting, it is key that flow through the cathode surface be good. To test this, a cell was mounted in a "wing” section that blocked flow through the cell edges and smoothed flow past the cathodes. Cell performance with flow parallel to the wing in the rotating-arm test tank was compared with performance of a bare cell having open edges and edge-on flow. The two cell configurations are shown in Figure 2 where the wing is mounted around the bare cell, smoothing the flow over it and blocking flow through its edges.

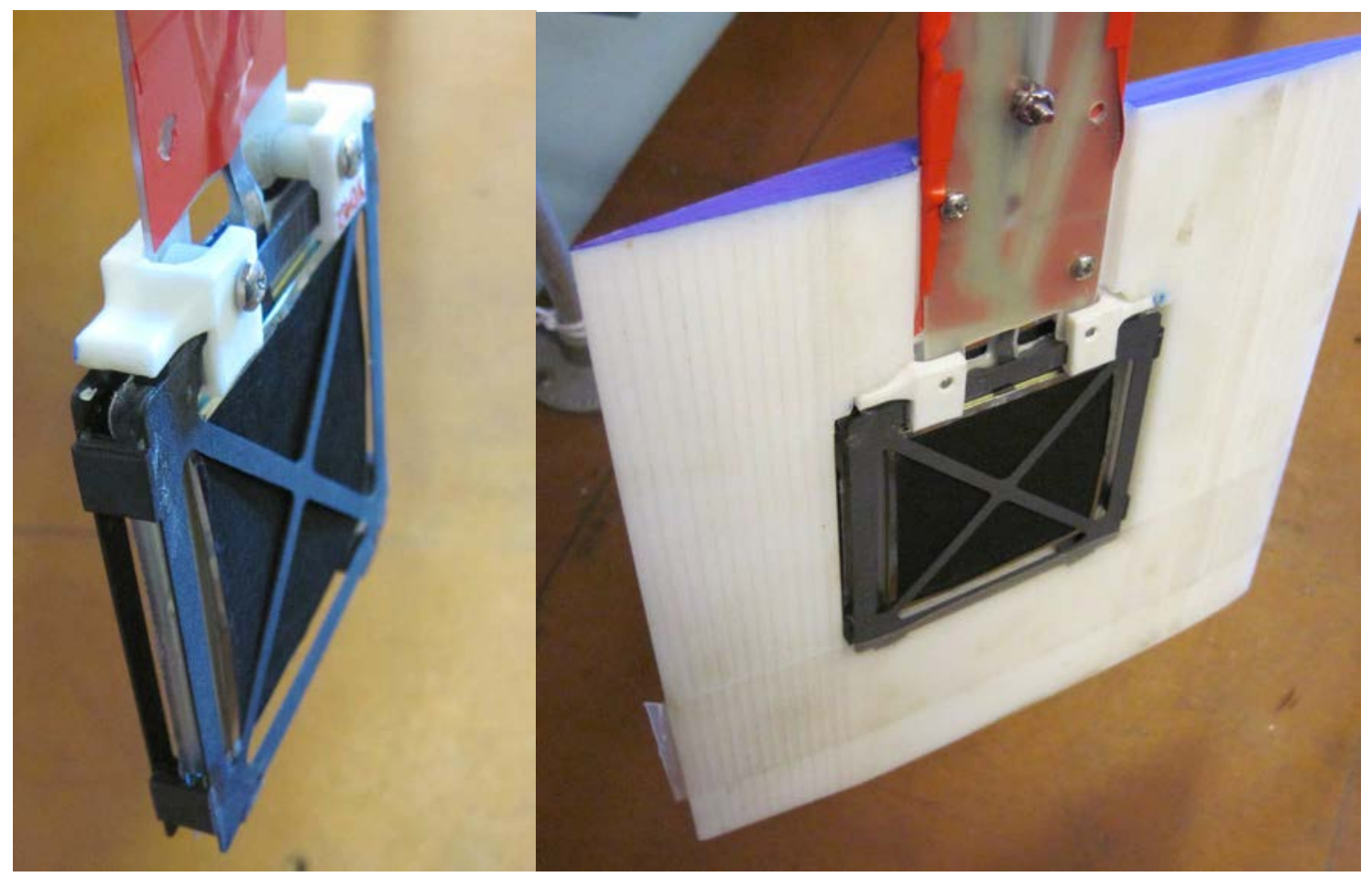

Figure 2. A bare PolyPlus cell (left) and a cell imbedded in a wing section (right) used to compare mass transfer through the cell edges and through the permeable cathodes exposed in both tests. 
Comparisons in the speed range 8-12 cm/s, and current densities of 0.12-0.35 ma/cm ${ }^{2}$ show a performance penalty for wing mounting that reached $200 \mathrm{mV}$ at the lowest speed and highest current density. Similar tests will be carried out for side-by-side mounting of multiple cells.

\section{IMPACT/APPLICATIONS}

The capabilities of sensor systems on autonomous ocean-observing vehicles and the sustained speed and range of those vehicles are all directly proportional to the energy density of the vehicle's power source. Because lithium-seawater batteries potentially significantly increase this energy density, studies of the performance they can achieve in the ocean, and of ways to maximize it, are pertinent to the evolution of long-term scientific and Navy ocean observing systems.

\section{RELATED PROJECTS}

The PIs have no related projects; PolyPlus may. 